\section{IN MEMORIAM: Professor ANDREA BAČANI, PhD, BSc in Geology (1954 - 2018)}

The Mining-Geology-Petroleum Engineering Bulletin UDC: 55

DOI: 10.17794/rgn.2018.3.12

Non-reviewed note

\author{
Zoran Nakić'; Darko Mayer' ${ }^{1}$; Kristijan Posavec'; Ranko Žugaj'; \\ Jelena Parlov'; Dario Perković'; Zoran Kovač ${ }^{1}$ \\ ${ }^{1}$ University of Zagreb, Faculty of Mining, Geology and Petroleum Engineering, Pierottijeva 6, Zagreb, Croatia
}

Our dear and highly respected Andrea Bačani (née Župarić), full professor of the Faculty of Mining, Geology and Petroleum Engineering, University of Zagreb, passed away on February 24, 2018.

Professor Bačani was employed at the Department of Geology and Geological Engineering at the Faculty of Mining, Geology and Petroleum Engineering, University of Zagreb from 1979 until 2018. For the first 18 years she was a collaborator in the projects of Professor Pavao Miletić, and in 1992 she became an assistant. Since then, she advanced through all professional levels until she became a tenured full professor in 2011.

In the course of her long and fruitful working life she dedicated herself to scientific, professional and pedagogical work in the area of technical sciences, field of Mining, Petroleum Engineering and Geological Engineering, to the branch of Geological Engineering. She was an accomplished hydrogeologist.

Professor Andrea Bačani was born on August 12, 1954 in Zagreb, where she finished elementary school and a comprehensive secondary school. She graduated from the Faculty of Mining, Geology and Petroleum Engineering, University of Zagreb on December 22, 1978 and became a BSc of Geology. The title of her graduation thesis was Engineering-geological characteristics of the wider area of the Brezovo polje-Žirovac route. Professor Bačani had shown an interest in pursuing a scientific career even as a student when she was awarded a Chancellor's Award in the academic year 1977/1978. This award is presented only to the best students.

Her exceedingly rich pedagogical, scientific and professional career began in 1979 at the Faculty of Mining, Geology and Petroleum Engineering, University of Zagreb, when she started working at the Department for Engineering Geology, Hydrogeology, Geology of coal and petroleum as a professional collaborator. She immediately started working on hydrogeological exploration for the Eastern Slavonian Posavina water supply project, led by Professor Pavao Miletić. Her tasks consisted of controlling the creation of structural and piezometric drill holes and test and exploratory wells as well as test

Corresponding author: Zoran Nakić

zoran.nakic@rgn.hr pumping. The work was conducted across a wide area to the north of the Sava River, between Slavonski Brod in the west and Lipovac in the east as well as south of the watershed dividing the catchment areas of the rivers Sava and Drava. Since that work was occasionally done using as many as three drilling apparatuses, it was necessary to travel very frequently, sometimes as much as twice or three times a week to that area. Andrea immediately took part in this work, showing a great deal of interest. With her collaborators she travelled many dozens of times to Slavonia, frequently driving her own car, Zastava 850 , and in this way gathered her first experiences as a driver. She was very successful working in the field although the work was often fraught with difficulty. Through her approach and behaviour, she asserted her authority and earned the respect of her colleagues and co-workers. She also worked in the laboratory, interpreting the data, creating studies and research programs as well as preparing competition materials.

She defended her Master's thesis at the Faculty of Science, University of Zagreb on May 18, 1990. The thesis was entitled The influence of poorly permeable sediments on the renewal of groundwater supply using the example of Eastern Slavonia.

Hydrogeology as well as Eastern Slavonia remain in the focus of her scientific interest and exploration in the next stage of her career as well. While working on her $\mathrm{PhD}$ thesis, she explored the characteristics of hydraulic borders of aquifers at the catchment areas of the Sava and Drava rivers in Eastern Slavonia. She invested an exceeding amount of work in her exploration, both in the field and in her study. Although many of them were already processed, she frequently had to gather and reprocess very extensive basic substructures. While discussing professional and scientific topics connected to Eastern Slavonia with her collaborators, she was always joyful and smiling, proving that she regarded Eastern Slavonia as an area she was very intimately connected to, an area she invested a lot of effort in and knew really well. After seven years of exploration of aquifer characteristics in Eastern Slavonia, Andrea Bačani defended her doctoral dissertation entitled Characteristics of hydraulic borders of aquifers at the catchment area of the Sava and Drava rivers in Eastern Slavonia on May 16, 
1997 at the Faculty of Mining, Geology and Petroleum Engineering, University of Zagreb. This enabled her to become Assistant Professor very quickly, in 1998.

Professor Andrea Bačani chose hydrogeology as the subject of her pedagogical, scientific and exploratory work through the choice of topics of her Master's Thesis and her doctoral dissertation. After the defence of her doctoral dissertation, she specialized in the exploration of groundwater supply, groundwater protection, groundwater flow modelling and pollution transportation methods.

Very frequently she included young colleagues in her scientific and exploratory work. To them, she was always an excellent leader and support allowing them to get to the very core of any scientific problem and perform all, even the scientifically most demanding research successfully. She published, most frequently as a co-author with young colleagues, 79 scientific papers, five of which were published in magazines quoted in tertiary publications, 18 in magazines published in secondary publications, 52 papers were published in the proceedings of international and domestic scientific conferences, and one chapter in a book. Professor Bačani was also the author of three university textbooks.

Professor Bačani gave one invited lecture at an international conference and four invited lectures at domestic scientific conferences. She lectured at 16 international and 12 domestic scientific conferences and gave four public lectures.

Professor Bačani was also the leader of the Ministry of Science, education and Sport's scientific project entitled: The dynamics, protection and exploitation reserves of Croatia's groundwaters in the period from 2008 until 2013. As a collaborator, she participated in numerous international and domestic scientific projects. Among international projects, we shall mention only GENESIS - Groundwater and dependent Ecosystems: New Scientific basis on climate change and land-use impacts for the update of the EU Groundwater Directive (FP7-ENV-2008-1) from 2009 until 2013. From 1981 until 2006 she also participated in four domestic scientific projects: Management of Croatian groundwaters, Complex hydrogeological exploration of Croatian lowlands, An analysis of Croatian hydrogeological explorations and Exploitation reserves of Croatian groundwaters.

Professor Bačani reviewed three University textbooks, one compendium and two teaching materials as well as more than 40 scientific papers. Her reviews were always carried out very carefully and thoroughly and have always greatly helped the authors.

From 2007 until 2018 she was a member and, for a while, acting chairperson of the Board for the fields of Chemical Engineering, Mining, Petroleum and Geological Engineering, Metallurgy, Textile Technology and Graphic Technology.

Her professional career is also well worth mentioning. At the Ministry of Environment and Energy, she served as the president and member of committees for the evaluation of environmental impact of more than 20 projects. At the Faculty of Mining, Geology and Petroleum Engineering, University of Zagreb, she worked on more than 90 professional projects and led more than half of them. We would like to single out the project she worked on for many years as a collaborator of Professor Pavao Miletić, in collaboration with Croatian waters entitled Registry and management of Croatian groundwaters. After Professor Miletić's retired, the current professor Emeritus Darko Mayer led the project for a short while. Professor Bačani took over the project from Professor Mayer and continued as its successful leader since 2002.

Professor Bačani was a member of the Croatian Geological Society, a member of the Head Committee of the Croatian Hydrological Society and a member of numerous international professional societies, such as International Association of Hydrogeologists, Association of Ground Water Scientists and Engineers as well as American Geophysical Union.

Professor Andrea Bačani was a greatly appreciated teacher at the Faculty of Mining, Geology and Petroleum Engineering, University of Zagreb. Aside from this institution, she also taught at high schools and other institutions of higher learning in the Republic of Croatia.

In the period before the advent of the Bologna system, Professor Bačani taught the following courses at the Faculty of Mining, Geology and Petroleum Engineering, University of Zagreb: Hydrogeology I, Hydrogeology and Engineering Geology and Methods of operational exploration in hydrogeology. Within the scope of the Bologna study programme, Professor Bačani defined the contents and taught at the pregraduate as well as the graduate study levels at the Faculty of Mining, Geology and Petroleum Engineering, University of Zagreb the following courses: Hydrogeology I (pregraduate study of Geological Engineering), Hydrology and Hydrogeology (pregraduate study of Mining), Hydrogeology II (graduate study of Geological Engineering) and Methods of operational exploration in hydrogeology (graduate study of Geological Engineering). At the doctoral study at the Faculty of Mining, Geology and Petroleum Engineering, University of Zagreb she taught the following courses: Petroleum hydrogeology and Operational exploration in hydrogeology.

At the High school for chemistry and technology Professor Bačani taught two courses: Engineering Geology and Hydrogeology and Geology of oil, gas and coal beds in the period from 1983 until 1988. She also taught a course in Hydrogeology at the Faculty of Science, University of Zagreb starting in 1997 and a course in Geology and Petrology at the faculty of Civil Engineering, University of Zagreb from 1985 until 1990.

She also had many duties in the teaching process which she performed very conscientiously since 1992 . These are only some of the most important ones: 
- Head of summer practice for students of Geology,

- President of the Committee for enrolment of students into their first year of studies of pregraduate and graduate studies at the Faculty of Mining, Geology and Petroleum Engineering, University of Zagreb,

- Faculty of Mining, Geology and Petroleum Engineering, University of Zagreb's coordinator at the Agency for Science and Higher Education,

- President of the Committee for final and graduation exams at the Faculty of Mining, Geology and Petroleum Engineering, University of Zagreb.

In cooperation with Professor Emeritus Darko Mayer, she wrote examples for the textbook of Professor Pavao Miletić, PhD and Professor Marija Heinrich Miletić, $\mathrm{PhD}$ : Introduction to quantitative hydrogeology in the very beginning of her academic career, in 1981.

Professor Bačani is the author of three University textbooks: Hydrogeology I - first issue was published in 2006 - as well as a co-author of two additional textbooks: Methods of operational exploration in hydrogeology, published in 2011 with Professor Kristijan Posavec and Hydrogeology - application in civil engineering, published in 2012, co-authored by Professor Tatjana Vlahović, PhD.

The highest achievement of educational work, and permanent legacy of each professor, is written material. It is why here is mentioned very first university book of Prof. Andrea Bačani, as sole author.

That book, Hydrology I, had been present in the Croatian Waters in Zagreb, organised by the Croatian Hydrological Society. It was published as university script, as the author strictly insisted. However, such descriptive and concise educational material, including strict and clear definitions of all basic hydrogeological terms and methods, is extraordinary well-prepared handbook, even book, what had been confirmed with several issues through years, after it was sold-out. The value of that book is permanent. It was dedicated to the most loved persons in her life - daughter Laura and son Bruno.

Professor Andrea Bačani was an exceptional person in every way. Through her work she contributed immensely to the scientific, pedagogical and professional community, the Faculty of Mining, Geology and Petroleum Engineering, University of Zagreb, and particularly to her own Department of Geology and Geological Engineering. Not only was she a member of the Department, she also very successfully served as its Head in two terms. Her colleagues respected and appreciated her for her professionalism, expertise and dedication to hy- drogeology. She loved her work very much and worked on each project with great enthusiasm, both as a team leader and as a team member. She accepted all professional challenges with great gusto. Professor Bačani contributed beyond measure to the education of a great number of today's engineers and scientists, whom she taught the basics of hydrogeology.

Her students loved her very much and held her lectures in great esteem, particularly her simplicity of language and expression and the ease with which she transferred all, including the most demanding hydrogeological topics in a clear and easily understandable way. This is clearly visible from the data regarding the number of students who attended her lectures as well as from the data regarding her supervision of seven $\mathrm{PhD}$ theses, two Master's theses and more than 60 final and graduation theses. The average grade awarded her by the students always rose high above the average grade of other teachers both at the Faculty of Mining, Geology and Petroleum Engineering and at the University of Zagreb. Professor Andrea Bačani prepared extensively for every lecture she gave, whether they were a part of her regular classes or invited lectures. She paid particular attention to field classes which she designed, organized and held regularly.

It is particularly important to point out that professor Andrea Bačani was a truly wonderful person, kind and good. She was simple and easy to communicate with, warm and sensitive to all in need, trusting towards her collaborators, colleagues and students. These virtues were for her completely natural and for all of us, who knew her, so special. It is rare for a person to touch the people around her with her personality and character, good temper and warmth, enrich us and make us better human beings. Our dear Andrea was all that and much more. First and foremost, she was a wonderful human being.

She was always in a good mood, always ready to travel, to jump into water from waterfalls that much younger divers were afraid to jump from. She simply adored nature and travelling.

More than anything else, she loved her children. She was very proud of her daughter Laura's study success, her son Bruno's diving adventures and would do anything for them.

Our dear Andrea was a person we could all trust and a true support to all of us. We want to thank her for all that she was and all that she gave as our colleague and our friend. The memory of her at our Department and our Faculty will live forever. For that we are all immeasurably grateful.

\section{Authors:}

Zoran Nakić (Professor, PhD), Darko Mayer (retired Professor, PhD), Kristijan Posavec (Professor, PhD), Ranko Žugaj (retired Professor, PhD), Jelena Parlov (Assistant Professor, PhD), Dario Perković (Assistant Professor, PhD), Zoran Kovač (PhD).

The Mining-Geology-Petroleum Engineering Bulletin and the authors @ , 2018, pp. 121-127, DOI: 10.1177/rgn.2018.1.1 